\title{
Leadership in Higher Education: Facts, Fictions and Futures - Introduction to the Special Issue
}

\author{
Published in Leadership, 5(3), 291-298 \\ Richard Bolden (contact author) \\ Centre for Leadership Studies \\ University of Exeter \\ Xfi Building \\ Rennes Drive \\ Exeter \\ EX4 4ST \\ UK \\ Tel: +44 (0)1392 262579 \\ Email: Richard.Bolden@exeter.ac.uk \\ Georgy Petrov \\ Kingston University Business School \\ Jonathan Gosling \\ Centre for Leadership Studies, University of Exeter
}

\section{Alan Bryman \\ School of Management, University of Leicester}

This special issue arose out of a symposium hosted by the editors in conjunction with the Leadership Foundation for Higher Education (LFHE) at St Georges House in Windsor Castle on $31^{\text {st }}$ March- $1^{\text {st }}$ April $2008^{1}$. This event was conceived of partly as an opportunity to review the outcomes of a raft of research recently completed on behalf of the LFHE (see http://www.lfhe.ac.uk/research/projects for further details) as well as similar work on further education (FE), for the Centre for Excellence in Leadership (CEL), and school education, for the National College for School Leadership (NCSL). Above all, however, we saw this as an opportunity for reflection and theorisation - to consider the 'big issues' facing our sector and to take stock of the successes, challenges and possible futures for leadership within HE.

The event was attended by 25 people, each invited because of their extensive experience of researching and in many cases also practicing leadership in HE, or the related fields of FE or schools. Amongst us were two current or previous vice chancellors, two registrars, 12 professors and numerous heads of departments and research centres. The event was structured around a series of 13 paper presentations, each accompanied by a detailed response from a discussant or a group debate.

Sessions were broadly grouped under one of seven themes: leadership in context, leadership and purpose, leadership and management, leadership and change, leadership and identity, leadership in other parts of the education sector (FE and schools), and leadership discourses. It concluded with a discussion of key research issues and priorities for further study.

\footnotetext{
${ }^{1}$ The authors would like to thank the LFHE for their support of this event and the research that led up to it.
} 
Given the historical and cultural significance of higher education Windsor Castle seemed an ideal venue to reflect on its past, present and future. Universities are some of our oldest surviving organisations, with strong links to political, corporate, cultural and community establishments. The ability to educate the future generation of professionals, business people, politicians and employees, and to create new knowledge and theory through research, is both a privilege and a serious responsibility. Whilst universities and HE colleges may lay claim to substantial influence over social, cultural and economic trends so too, are they partly responsible for current challenges and inequalities. In business and management academia has, at least partly, been held to blame for the proliferation of negative and self-serving business practices (see, for example, Bennis and O'Toole, 2005; Ghoshal, 2005; Hambrick, 2007) and there continue to be lively debates over the role of HE in society (see, for example, Beverungen, Dunne and Sørensen, 2008; Shattock, 2006; DfES, 2003) and the extent to which HE provision meets the needs of learners and employers (see Bolden and Petrov (2008) for a review).

In the current climate of economic recession, environmental change and social fragmentation HE finds itself at a crossroads. Higher education institutions (HEIs) are expected to deliver on an ever-expanding range of often conflicting goals and priorities. They are charged with contributing to the national economy (and being held accountable for their own expenditure), mass education of young students, closer engagement with employers and the delivery of work based learning for mature students, as well as producing cutting edge international research.

The response of HE institutions to this expanding array of demands has arguably been to shift from collegial decision making towards more managerial, corporate and/or entrepreneurial models (Bargh, Scott and Smith, 1996; Clark, 1998; McNay, 1995). Yet managerial, corporate and entrepreneurial approaches to management and leadership do not sit well with certain parts of the sector and must be enacted within ideological expectations of collegiality, collaboration and participative decision making (Henkel, 1997; Kogan and Hanney, 2000). Consequently, it can be argued, the rise of managerial and corporate approaches to leadership entails attempts to moderate these very expectations in order to further organisational ends - what Deem et al. (2007) refer to as 'new managerialism'. HEIs are neither fully private nor public sector organisations but are charged with the tasks and administrative requirements of both. Sastry and Bekandria (2007) have argued that rather than aspiring to mimic the prevalent leadership and management approaches within either of these sectors we may be better served by considering how to develop our own and, in so doing, may support the development of alternative ways of organising from which others beyond our sector may learn - both for the practice and theorisation of leadership.

In addition to the ever present need to 'do more with less' universities are also facing increased competition from other organisations. HE is now a global industry (Fielden, 2007) and, with the expansion of work-based learning, other providers are taking on responsibility for the provision and accreditation of higher skills development. In the UK, for example, this is the first year that an FE institution (Newcastle College) has received more money from the national funding council for its provision of $\mathrm{HE}$ than several universities. Indeed, for 2009-10 a total of $£ 184$ million has been allocated to FE colleges for the provision of HE (HEFCE, 2009). 
Whilst this is still only a very small proportion (4\%) of the overall recurrent HE teaching grant it may well mark the start of a shift in emphasis in which the futures of FE and HE become inextricably entwined. Colleges such as Newcastle clearly see the opportunity to play a more significant role in HE provision, expressing a desire "to be a polytechnic as that reflects our mission of being close to employers and delivering work-relevant programmes to assist people develop their careers" (Principal Jackie Fisher, cited in FE Focus, 2009). Increasingly universities must work alongside (and sometimes in competition with) FE colleges for the provision of $\mathrm{HE}$ in the community and it may be argued that "colleges have smashed the university monopoly on higher education, not only in terms of the scale of provision but the paradigm" (FE Focus, 2009).

So it was with thoughts about the changing context of HE in mind that we convened the symposium in spring 2008. This event came at the end of an intense period of preparation for the 2008 Research Assessment Exercise (RAE) in the UK and whilst universities were still speculating about the outcomes and their implications for the manner in which research funding would be distributed between institutions ${ }^{2}$. As the last in a series of RAEs and prior to clarification on the nature of its successor, the Research Excellence Framework (REF), this felt like a watershed moment - a brief interlude before the sector prepared, repaired and restructured itself for what lay ahead. The papers included in this special issue give a good cross section of the debates that were had during this event, the ways in which the sector is changing in the UK and elsewhere and the implications for leadership and management practice, research and development.

The opening essay sets the scene, locating the study of leadership in the context of intensifying managerialism. The reasons for this are manifold and summarised here, chiefly with the aim of focusing reflexively on the way(s) in which leadership has been construed by the research community. In particular, the authors consider why the concept of 'distributed leadership' has been at the forefront of much policy and research in this sector, and point to the rhetorical function of this and related terminology. It is hoped that this essay provides a critical departure point for the original and theoretically substantive papers that follow.

The next article, by Robin Middlehurst, Helen Goreham and Steve Woodfield, asks the question "why research leadership in higher education?" Drawing particularly on the experiences of the LFHE, with their remit of supporting and developing leadership

\footnotetext{
${ }^{2}$ The Research Assessment Exercise (RAE) was introduced in the UK in 1986 and assessed academic performance every 3-7 years on the basis of research outputs (see http://www.rae.ac.uk). For the 2008 RAE universities submitted their entries in November 2007, with an announcement of rankings in December 2008. RAE rankings are used by the HE funding councils in the UK for the distribution of research funding and, whilst it was expected that this would be focussed primarily on the larger research-intensive universities, the funding announcement from the Higher Education Funding Council for England (HEFCE) in March 2009 indicated a far broader spread of funding than anticipated due to the wide spread of research excellence identified in the RAE results. The Research Excellence Framework (REF), replacing the RAE, is expected retain a focus on research outputs, but will also take greater account of $\mathrm{PhD}$ supervisions, research grant income and research impact. The REF will combine quantitative indicators - including bibliometric indicators wherever these are appropriate - and expert review. Which of these elements are employed, and the balance between them, will vary according to the subject. The economic and social impact of research, as well as impact upon public policy, will also contribute to the overall assessment of quality (see http://www.hefce.ac.uk/Research/ref/ for further details).
} 
in the sector, these authors turn their attention to the practical implications of research for those involved in leadership practice, development and policy-formulation. The paper begins with an overview of the field of HE leadership research before reflecting in depth on a number of recently completed studies commissioned by the Foundation. They conclude by considering how research such as this may play an important role in mediating between political and institutional perspectives on leadership in HE.

The paper by Alan Bryman and Simon Lilley reports findings from a study that explores perceptions of effective leadership in HE, with a particular focus on the role of 'head of department' - a key yet under-investigated role. Their methodology draws on the collective expertise of a group of leadership researchers based within UK HE institutions to outline both opportunities and challenges for understanding leadership within the sector. Whilst leadership scholars are particularly well placed to comment on the quality of leadership in HE and, in many cases hold significant leadership roles themselves, their very proximity to the subject of investigation may render it hard to be 'objective'. Interviews were conducted, for example, during a period industrial dispute, in which both interviewees and the leaders to whom they referred were very much involved. In exploring these particular leadership discourses Bryman and Lilley identify many familiar accounts of leadership, as well as some new ones. In particular the issue of context seems significant yet difficult to pin down. In HE the context, it seems, is both everything and nothing - both essential to how we understand and enact leadership and, to some extent, irrelevant - perhaps good leadership is good leadership no matter where it happens!

The next article, by Harry de Boer and Leo Goedegebuure, applies a similar focus on the role of the 'academic dean'. Much as other authors have proposed for middle managers (e.g. Huy, 2001), de Boer and Goedegebuure propose that the role of dean is pivotal due to the manner in which it is the point of interface between top-down strategy and bottom-up operations. Through their article, these authors highlight that in many countries the role of the academic dean is in flux and they argue that to a significant extent the nature of these changes are inextricably bound up with the new public sector managerialism that is making is growing incursions into the sector. Indeed, deans are viewed as at the heart of the universities' attempts to modernise their managerial structures. The authors conclude that, given the significance of the role of deans, the evidence base on how they run their faculties and how effective this is, remains scant and in need of further study.

In their article David and Margaret Collinson offer a comparative account of how leadership is perceived and enacted in another part of the education sector - one that is making growing incursions into the provision of higher skills either through direct delivery of HE or through partnership with universities. Through detailed empirical work in FE colleges these authors argue that employees show a preference for 'blended leadership' that combines elements of "both delegation and direction, both proximity and distance and both internal and external engagement". These findings challenge an overly simplistic dichotomy between 'individual' and 'distributed' leadership proposing, instead, a need to reconcile these distinctions and embrace a more dialectical approach to the theorisation and practice of leadership.

The final paper draws together a number of themes raised throughout this special issue, in particular, the difficulties posed by dominant discourses and constructs of 
leadership. Peter Gronn calls for a shift in how we conceive of leadership practice, away from descriptors such as 'distributed', 'transformational' and 'situational' (each of which are imbued with normative assumptions on 'good' or 'effective' leadership) to a revised unit of analysis: that of leadership 'configuration'. Through reference to a range of studies, both within and beyond $\mathrm{HE}$, Gronn provides a convincing account of how leadership practice takes many different forms, arranged through "time-, space-, context- and membership-bound configuration(s) of influence-based relationships". In diverting our gaze from the dominant narratives of leadership, he enables us take a more systemic perspective on leadership in organisations and to suspend our judgement on what may be considered most appropriate or desirable. He concludes by considering the implications of such a shift for future research into leadership practice.

Together these papers give a good overview of the current state of the field of leadership theory and research in HE and point towards new avenues of enquiry that should enhance both the study and practice of leadership within this sector as well as elsewhere. They are inevitably, however, only a partial voice. They are largely, although not solely, based on research conducted in the UK. They tend to privilege the perspective of academic leaders in more traditional, research intensive universities, perhaps underestimating the significance of leaders within professional services and 'boundary-spanning' roles (Whitchurch, 2008) and the newer, more teaching and employer focussed institutions. And they were written during a particular period of discourse about the role and function of $\mathrm{HE}$ and the significance of leadership. So what are some of the areas we may have missed and which are most worthy of further investigation?

The symposium from which these papers arose concluded by considering outstanding issues and priorities for further theorisation and research. These are described in Table 1. From this table it is clear that there is still much to be done. In particular we need to take a more holistic view of leadership in HE that recognises the contextual and systemic nature of effective leadership practice. This is an area that is infused with political and ideological assumptions and agendas and we should be wary of accepting accounts of leadership at face value. We would be well advised to bring a degree of scepticism to our enquiries yet, for those of us in academic positions, by virtue of our special relationship to HE, a sector in which we work and in which many of us have invested a substantial part of our past and future aspirations, good leadership really matters.

\section{[INSERT TABLE 1 ABOUT HERE]}

For those of you who currently or have previously studied leadership in HE we hope that the collection of papers in this special issue revitalises your interest in the subject. For those of you who are part of the sector and yet to study leadership in HE we hope that we have tweaked your curiosity and desire to reflect more consciously on the nature and quality of leadership around you. And for those of you outside of the sector, with little desire to enter the domain of HE leadership, we hope that we have provided some interesting insights into a rather unique sector, yet one with parallels to many others.

\section{REFERENCES}


Alvesson, M. and Sveningsson, S. (2003) The great disappearing act: difficulties in doing 'leadership', The Leadership Quarterly, 14, 359-381.

Bargh, C., Scott, P. and Smith, D. (1996) Governing Universities: Changing the Culture? Buckingham: SRHE and OU Press.

Bennis, W. and O'Toole, J. (2005) How business schools lost their way, Harvard Business Review, 83(5), 96-104.

Beverungen, A., Dunne, S. and Sørensen, B.M. (2008) University, failed, Ephemera, 8(3): 232-237, URL: [www.ephemeraweb.org].

Bolden, R. and Petrov, G. (2008) Employer Engagement with Higher Education: A literature review. Report compiled for the South West Higher Level Skills Project on behalf of HERDA South West and HEFCE, Centre for Leadership Studies, University of Exeter. URL: [http://tinyurl.com/66r5ye]

Clark, B.R. (1998) Creating Entrepreneurial Universities: Organizational Pathways of Transformation. Oxford: Pergamon.

Deem, R., Reed, M. and Hillyard, S. (2007) Knowledge, Higher Education, and the New Managerialism: The Changing Management of UK Universities. Oxford: Oxford University Press.

DfES (2003) The Future of Higher Education, Norwich: The Stationery Office. URL: [http://www.dcsf.gov.uk/hegateway/strategy/hestrategy/].

FE Focus (2009) Colleges reaping rewards of their approach to HE, Times Education Supplement, 06/03/09.

URL: [www.tes.co.uk/article.aspx ?storycode $=6009801]$.

Fielden, J. (2007) Global Horizons for UK Universities. London: Council for Industry and Higher Education.

Ghoshal, S. (2005) Bad management theories are destroying good management practices, Academy of Management Learning and Education, 4(1), 75-91.

Guest, D. and Clinton, M. (2007) Human Resource Management and University Performance: Final Report. London: Leadership Foundation for Higher Education.

Hambrick, D. (2007) The field of management's devotion to theory: too much of a good thing? Academy of Management Journal, 50(6), 1346-1352.

HEFCE (2009) Recurrent grants for 2009-10. Bristol: Higher Education Funding Council for England. URL: [www.hefce.ac.uk/pubs/hefce/2009/09_08/].

Henkel, M. (1997) 'Academic values and the university as corporate enterprise', Higher Education Quarterly, 51(2), 134-43.

Huy, Q.N. (2001) In praise of middle managers, Harvard Business Review. 79(5) $72-$ 79.

Kogan, M. and Hanney, S. (2000) Reforming Higher Education. London: Jessica Kingsley.

McNay, I. (1995) 'From the collegial academy to corporate enterprise: the changing cultures of universities'. In T. Schuller (ed.) The Changing University? Buckingham: SRHE and OU Press.

Sastry, T. and Bekhradnia, B. (2007) Higher Education, Skills and Employer Engagement. Oxford: HEPI.

Shattock, M. (2006) Managing Good Governance in Higher Education. Maidenhead: Open University Press.

Whitchurch, C. (2008) Shifting identities and blurring boundaries: the emergence of third space professionals in UK higher education, Higher Education Quarterly, 62(4) 377-396. 
1. POWER AND POLITICS: the majority of management and leadership research in HE, as elsewhere, is grounded in psychological and behavioural approaches and, as such, may underestimate the dynamics of power and politics in shaping perceptions and the enactment of leadership. An increase in sociological perspectives and consideration of the broader social dynamics of influence and authority, in particular the significance of discourse, would enhance the field.

2. PATHWAYS TO LEADERSHIP: current research on leadership in HE tends to focus almost exclusively on the holders of formal academic-management roles. As a result, there is insufficient understanding of how leadership is perceived amongst people at earlier stages in their careers and how experiences and perceptions change over time. Furthermore, whilst attention may be given to the transition into a formal leadership role (i.e. development needs, etc.) very little consideration is given to exit from these roles and what it means for people re-entering predominantly academic roles after a period in 'management'.

3. INTERFACES AND BOUNDARIES: whilst something is known of both academic and administrative functions within HE, little research explicitly explores the interface between these areas and the extent to which new, 'hybrid' or 'boundary-spanning' roles (Whitchurch, 2008) may be emerging. Furthermore, with the increasing permeability of the HE-FE divide and increased pressures for HEIs to work within collaborative partnerships greater research and theorisation into the nature of trans-occupational and trans-organisational leadership is required.

4. THE CHALLENGE OF CONTEXT: with the changing context of HE we are beginning to see greater differentiation between institutions on the basis of mission, strategy, location and provision. To this extent, a more fine-grained analysis of HE contexts and how these relate to effective styles of leadership and management would be beneficial. A greater number of comparative studies of $\mathrm{HE}$ in different countries and in comparison to different sectors would better illuminate the contextual specificities that influence performance against a range of criteria. One striking realisation from discussions with colleagues from the school sector was the extent to which 'learners' are the central focus of much of their work yet relatively absent within analyses of leadership in HE.

5. LEADERSHIP EFFECTIVENESS AND PERFORMANCE: the diversity of organisational objectives and outcomes in HE makes it difficult to isolate robust performance and success criteria. Much leadership theory and research in HE is descriptive or normative, yet not linked to measures of effectiveness. Thus, whilst we may have elaborate descriptions of the behaviours and styles of vice chancellors, deans, heads of department, etc., there is little convincing evidence to indicate which are most effective and why. More research in this area, as well as the causes of bad and/or ineffective leadership, would give a stronger evidence base for the development and promotion of different practices.

6. ORGANISATIONAL PRACTICES AND PROCESSES: how do organisational systems for the recognition, reward and development of leadership and management (e.g. human resource management (HRM), finances, staff development, etc.) facilitate and/or inhibit effective leadership performance at individual, group and organisational levels? In the light of findings, such as Guest and Clinton (2007), that indicate no clear relationship between HRM practices and organisational performance in universities how do we make better sense of the manner in which effective leadership capacity is, at least in part, embedded within organisation systems and structures?

7. ALTERNATIVES TO LEADERSHIP: the notion of 'leadership' has now become such a dominant discourse within HE that it may distort findings. Great value may arise from utilising alternative conceptualisations and frames that challenge or counter pose this viewpoint. Examples may include investigating effective 'teamwork', 'partnerships', 'identities', 'decision making', 'practices' or even 'followership' within HE. We also, arguably, would benefit from more critical studies of leadership that challenge embedded assumptions about its utility and/or necessity (e.g. Alvesson and Sveningsson, 2003).

8. METHODOLOGICAL ISSUES: in the light of these recommendations, what are the most useful questions to be asking about leadership in HE and how can these best be addressed? How can we move away from anecdotes and accounts from 'the usual suspects' to a more informed, critical and reflexive understanding of the nature of leadership in large, complex organisations such as universities. Is it possible to take deeper slices through institutions to unearth experiences, expectations and contributions to leadership at all levels?

Table 1 - Priorities for further research (identified at Windsor symposium, 01/04/08) 


\section{Author Biographies}

Richard Bolden is a lecturer at the Centre for Leadership Studies at the University of Exeter. His research interests span a wide range of topics including leadership in Higher Education, distributed leadership, leadership practice, leadership and management competencies, work-based learning and leadership development for organizational and social change. In addition, he teaches and supervises students on a range of programmes including the Exeter MA in Leadership Studies, MBA and CPD scheme.

Dr Georgy Petrov is a lecturer in Organisational Behaviour and Leadership at Kingston University Business School. Prior to joining Kingston in September 2008 Georgy was a researcher at the Centre for Leadership Studies, University of Exeter, working on a number of research projects. His research interests include leadership and leadership development in HE, corruption in HE, HE reform in transitional countries and employer engagement with HE.

Jonathan Gosling is Professor and Director of the Centre for Leadership Studies, University of Exeter Business School. His research is turning towards the interplay between language (as employed in the discursive construction of leadership) and group psychodynamics. But he is also interested in leadership development more generally, and is Distinguished Visiting Professor in Leadership Development at Insead, France. He is a board member or Fellow of a number of UK and European institutions concerned with leadership education.

Alan Bryman is Professor of Organisational and Social Research in and Head of the School of Management, University of Leicester, UK. His main research interests lie in research methodology, leadership, organizational analysis, and Disneyization. He is author or co-author of many books, including: Quantity and Quality in Social Research (Routledge, 1988), Social Research Methods (OUP, 2001, 2004, 2008), Business Research Methods (OUP, 2003, 2007), and Disneyization of Society (Sage, 2004). He is co-editor of The SAGE Encyclopedia of Social Science Research (Sage, 2004), Handbook of Data Analysis (Sage, 2004), and the Handbook of Organizational Research Methods (Sage, 2009). 